\title{
Two atypical new species of the genus Sectonema Thorne, 1930 (Nematoda, Dorylaimida, Aporcelaimidae) from Vietnam
}

\author{
Thi Anh Duong NGUYEN ${ }^{1}$, Joaquín ABOLAFIA ${ }^{2}$, Michael BONKOWSKI ${ }^{3}$, \\ Reyes PEÑA-SANTIAGO ${ }^{4}$ \& Sergio ÁLVAREZ-ORTEGA ${ }^{5, *}$ \\ ${ }^{1,3}$ Department of Terrestrial Ecology, Zoological Institute, University of Cologne, \\ Zülpicher Straße 47b, 50674 Cologne, Germany. \\ ${ }^{1}$ Institute of Ecology and Biological Resources, Vietnam Academy of Science and Technology, \\ 18 Hoang Quoc Viet, Hanoi, Vietnam. \\ 1, 2, 4,5 Departamento de Biología Animal, Biología Vegetal y Ecología, Universidad de Jaén, \\ Campus 'Las Lagunillas's/n, Edificio B3, 23071 Jaén, Spain. \\ "Corresponding author: saortega@ujaen.es \\ ${ }^{1}$ urn:Isid:zoobank.org:author:22D081FF-7764-4ECF-8C48-AF2EC20014FD \\ ${ }^{2}$ urn:Isid:zoobank.org:author:D7E30782-F6F2-48CA-B26F-9CA512FEC078 \\ ${ }^{3}$ urn:Isid:zoobank.org:author:6C0B083D-8A7E-4E0E-B03E-C00529DC4FC9 \\ ${ }^{4}$ urn:Isid:zoobank.org:author:0B263323-3533-48A6-9D5C-BFF39D87BD47 \\ ${ }^{5}$ urn:lsid:zoobank.org:author:68794F1F-07DB-4880-9D28-8D50028B32C7
}

\begin{abstract}
Two new species of the genus Sectonema from natural habitats of northern Vietnam are studied. This paper includes their descriptions, measurements, line illustrations, and light microscope (LM) and scanning electron microscope (SEM) pictures. Sectonema tropicum sp. nov. is characterized by a $2.56-$ $3.24 \mathrm{~mm}$ long body, 19-21 $\mu \mathrm{m}$ broad lip region, odontostyle $20-21 \mu \mathrm{m}$ long at its ventral side, 730 $834 \mu \mathrm{m}$ long neck, pharyngeal expansion occupying 52-59\% of total neck length, uterus a simple tube-like structure 150-242 $\mu \mathrm{m}$ long or 1.2-2.5 times the body diameter, pars refringens vaginae present, $V=48-52$, short (31-40 $\left.\mu \mathrm{m}, c=70-91, c^{\prime}=0.5-0.6\right)$ and rounded tail, 91-97 $\mu \mathrm{m}$ long spicules, and only one weakly developed ventromedian supplement. Sectonema vietnamense sp. nov. is characterized by its slender $(a=$ $33-49$ ) and 2.71-4.25 mm long body, 14-16 $\mu \mathrm{m}$ broad lip region, odontostyle 8-9 $\mu \mathrm{m}$ long at its ventral side, 716-918 $\mu \mathrm{m}$ long neck, pharyngeal expansion occupying $63-67 \%$ of total neck length, uterus simple and 209-242 $\mu \mathrm{m}$ long or 2.5-2.9 times the corresponding body diameter, pars refringens vaginae absent, $V=54$, short (34-39 $\left.\mu \mathrm{m}, c=70-115, c^{\prime}=0.6-0.8\right)$ and rounded tail, 59-75 $\mu \mathrm{m}$ long spicules, and three or four irregularly spaced ventromedian supplements bearing hiatus. Both species are also characterized by their nearly continuous lip region, an atypical feature in this genus. Molecular analysis of S. tropicum sp. nov. confirms that Sectonema is a natural (monophyletic) taxon, very close to Metaporcelaimus.
\end{abstract}

Keywords. D2-D3 expansion segments of LSU ribosomal DNA, morphology, morphometrics, taxonomy, SEM.

Nguyen T.A.D., Abolafia J., Bonkowski M., Peña-Santiago R. \& Álvarez-Ortega S. 2016. Two atypical new species of the genus Sectonema Thorne, 1930 (Nematoda, Dorylaimida, Aporcelaimidae) from Vietnam. European Journal of Taxonomy 171: 1-20. http://dx.doi.org/10.5852/ejt.2016.171 


\section{Introduction}

This contribution presents partial results of two nematological projects that overlap in their objectives. On the one hand, it is the second in a series of papers devoted to studying the nematode diversity of aporcelaims (family Aporcelaimidae Heyns, 1965) from natural areas of Vietnam, the first one (ÁlvarezOrtega et al. 2015) dealing with the representatives of the genus Aporcelaimoides Heyns, 1965. On the other hand, it is part of a general revision of the taxonomy and systematics of this dorylaimid group, in which the genera Aporcelaimellus Heyns, 1965, Metaporcelaimus Lordello, 1965 and Sectonema Thorne, 1930 have already received some attention (see for instance, and respectively, Álvarez-Ortega \& Peña-Santiago 2013; Álvarez-Ortega et al. 2013a; Peña-Santiago \& Álvarez-Ortega 2014a).

Interesting material belonging to the genus Sectonema was collected by the first author during several nematological surveys conducted in natural areas of Vietnam over the last years. The specimens are characterized by a nearly continuous lip region, indeed a rather atypical feature in Sectonema. Its detailed study revealed it to belong to two unknown forms, which are herein described.

\section{Material and methods}

\section{Nematodes}

Nematodes were collected from pristine areas in Northern Vietnam, extracted from soil samples using the methods by Baermann (1917) and Flegg (1967), relaxed and killed by heat, fixed in 4\% formaldehyde, and processed to anhydrous glycerine following Siddiqi's (1964) technique. Finally, the specimens were mounted on permanent glass slides to allow handling and observation under LM.

\section{Light microscopy}

Specimens were measured using a light Olympus BH-2 microscope equipped with differential interference contrast (DIC). Morphometrics included de Man's indices and the usual measurements. The location of the pharyngeal gland nuclei is expressed according to Loof \& Coomans (1970) and spicule terminology follows Peña-Santiago et al. (2014). Some of the best preserved specimens were photographed with a Nikon Eclipse 80i microscope and a Nikon DS digital camera. Raw photographs were edited using Adobe ${ }^{\circledR}$ Photoshop ${ }^{\circledR}$ CS version 8.0.1. Drawings were made using a camera lucida.

\section{Scanning electron microscopy}

After examination and identification, a few of the preserved specimens were selected for observation under SEM following the protocol by Abolafia \& Peña-Santiago (2005). The nematodes were hydrated in distilled water, dehydrated in a graded ethanol and acetone series, critical point dried, coated with gold, and observed with a Zeiss Merlin microscope.

\section{DNA extraction, PCR and sequencing}

DNA was extracted from individuals using the proteinase $\mathrm{K}$ protocol. Nematode material was transferred to an $0.5 \mathrm{ml}$ Eppendorf tube containing $18 \mu \mathrm{l}$ of Worm Lysis Buffer (WLB) (50 mM KCL, $10 \mathrm{mM}$ Tris pH 8.3, $2.5 \mathrm{mM} \mathrm{MgCl}_{2}, 0.45 \% \mathrm{NP} 40$, and $0.45 \%$ Tween 20$)$ and $2 \mu 1$ proteinase $\mathrm{K}\left(600 \mu \mathrm{g} \mathrm{ml}^{-1}\right)$ (Thermo Scientific). The tubes were incubated at $65^{\circ} \mathrm{C}(1 \mathrm{~h})$ and then at $95^{\circ} \mathrm{C}(15 \mathrm{~min})$. The PCR was performed in a $30 \mu 1$ final volume containing $24.9 \mu 1$ of sterile water, $0.6 \mu 1$ of each PCR primer, $0.6 \mu 1$ dNTP mixture, $0.3 \mu \mathrm{l} \mathrm{Taq}$ polyerase, $3 \mu \mathrm{l}$ Buffer 10x Thermo Scientific Green and $1 \mu 1$ of DNA extracted solution. The PCR amplification profile consisted of four min at $94^{\circ} \mathrm{C}, 35$ cycles of $1 \mathrm{~min}$ at $94^{\circ} \mathrm{C}, 1.5 \mathrm{~min}$ at $55^{\circ} \mathrm{C}$ and $2 \mathrm{~min}$ at $72^{\circ} \mathrm{C}$, followed by a final step of $10 \mathrm{~min}$ at $72^{\circ} \mathrm{C}$. The primers used for amplification were D2A (5'-ACAAGTACCGTGAGGGAAAGTTG-3') and D3B (5'-TCGGAAGGAACCAGCTACTA-3') for amplification of D2-D3 region of 28S (Subbotin et al. 2006). 
The PCR products were purified using Exo-SAP PCR cleanup containing $7 \mu 1$ of PCR product, $0.15 \mu 1$ Exonuclease I (Exo), $0.9 \mu 1$ Shrimps Phosphatase Alkali (SAP) and $1.95 \mu 1$ of sterile water. They were incubated at $37^{\circ} \mathrm{C}$ for $20 \mathrm{~min}$ and then heated up to $85^{\circ} \mathrm{C}$ for $15 \mathrm{~min}$; then the purified solution was diluted ten times.

The sequencing reaction was performed with $1 \mu \mathrm{l}$ of DNA purified template, $0.25 \mu 1$ BigDye v3.1, $2.25 \mu 15 \mathrm{x}$ BigDye sequencing buffer, $0.25 \mu \mathrm{l}$ of one primer. The mixture was heated up for $10 \mathrm{~s}$ at $96^{\circ} \mathrm{C}$, $5 \mathrm{~s}$ at $55^{\circ} \mathrm{C}$ repeated for 32 cycles followed by $4 \mathrm{~min}$ at $60^{\circ} \mathrm{C}$. The sequencing was performed at the Cologne Center for Genomics (CCG). The sequences obtained were submitted to the GenBank database under accession numbers KT868957 and KT868958.

\section{Phylogenetic analyses}

The newly obtained sequences were aligned with other forty two D2-D3 expansion segments of 28S rRNA gene sequences available in GenBank using ClustalX 1.83 (Thompson et al. 1997). Outgroup taxa were chosen according to the results of previously published data (Holterman et al. 2008; ÁlvarezOrtega et al. 2013b). Sequence alignments were manually edited using GenDoc 2.6.002 (Nicholas et al. 1997). The sequence dataset was analysed with Bayesian inference (BI) and Maximum Likelihood (ML) using MrBayes 3.1.2 (Huelsenbeck \& Ronquist 2001; Ronquist \& Huelsenbeck 2003) and MEGA 6 (Tamura et al. 2013), respectively. The best fit model of DNA evolution for BI was obtained using the program MrModeltest 2.2 (Nylander 2002) with the Akaike Information Criterion in conjunction with PAUP* 4b10 (Swofford 2003). BI analysis under the GTR $+\mathrm{G}+\mathrm{I}$ model was initiated with a random starting tree and run with the four Metropolis-coupled Markov chain Monte Carlo (MCMC) for $10^{6}$ generations. ML analysis was implemented under the best-fitting evolutionary model $(\mathrm{GTR}+\mathrm{I}+\mathrm{G})$, obtained using the program MEGA 6, and 1000 bootstrap replications. The topologies were used to generate a $50 \%$ majority rule consensus tree. Posterior probabilities (PP) are given on appropriate clades. The trees were visualised with the program FigTree v1.4.0 and drawn with Adobe Acrobat XI Pro 11.0.1.

\section{List of abbreviations}

a = body length / greatest body diameter

$\mathrm{b} \quad=$ body length / distance from anterior end to pharyngo-intestinal junction

$\mathrm{c} \quad=$ body length / tail length

$\mathrm{c}^{\prime}=$ tail length $/$ tail diameter at anus or cloaca

$\mathrm{DN}=$ distance from body anterior end to the nucleus of pharyngeal dorsal gland expressed as percentage (\%) of total neck length

DO $=$ distance from body anterior end to the outlet of pharyngeal dorsal gland expressed as percentage $(\%)$ of total neck length

$\mathrm{L} \quad=$ overall body length

$\mathrm{n} \quad=$ number of specimens on which measurements are based

$\mathrm{S}_{1} \mathrm{~N}_{1}=$ distance from body anterior end to the anterior nucleus of first pair of ventro-sublateral pharyngeal glands expressed as percentage (\%) of total neck length

$\mathrm{S}_{1} \mathrm{~N}_{2}=$ distance from body anterior end to the posterior nucleus of the first pair of ventro-sublateral pharyngeal glands expressed as percentage (\%) of total neck length

$\mathrm{S}_{2} \mathrm{~N}=$ distance from body anterior end to the nuclei of the second pair of ventro-sublateral pharyngeal glands expressed as percentage (\%) of total neck length

$\mathrm{V}=$ distance from body anterior end to vulva expressed as percentage (\%) of the body length. 


\title{
Results
}

\author{
Phylum Nematoda Cobb, 1932 \\ Class Enoplea Inglis, 1983 \\ Order Dorylaimida Pearse, 1942 \\ Family Aporcelaimidae Heyns, 1965 \\ Genus Sectonema Thorne, 1930 \\ Sectonema tropicum sp. nov. \\ urn:1sid:zoobank.org:act:014CA9CB-57EE-43BB-BBFF-0C1A7EBD522D
}

Figs 1-4; Table 1

\section{Diagnosis}

The new species is characterized by a $2.56-3.24 \mathrm{~mm}$ long body, lip region hardly offset by very weak depression and 19-21 $\mu \mathrm{m}$ broad, odontostyle 20-21 $\mu \mathrm{m}$ long at its ventral side and 6.6-7.1 times as long as wide, $730-834 \mu \mathrm{m}$ long neck, pharyngeal expansion $403-470 \mu \mathrm{m}$ long or occupying $52-59 \%$ of total neck length, uterus a simple tube-like structure 150-242 $\mu \mathrm{m}$ long or 1.2-2.5 times the body diameter, pars refringens vaginae present, $V=48-52$, short $\left(32-39 \mu \mathrm{m}, c=70-88, c^{\prime}=0.5-0.6\right)$ and rounded female tail, male tail similar to that of female $\left(31-40 \mu \mathrm{m}, c=73-91, c^{\prime}=0.5-0.6\right), 91-97 \mu \mathrm{m}$ long spicules, and only one weakly developed ventromedian supplement.

\section{Etymology}

The specific epithet refers to the tropical area where the new species was collected.

\section{Type material examined}

\section{Holotype}

VIETNAM: + , in acceptable state of preservation, Northern Vietnam, Cao Bang Province, Pia Oac Natural Reserve, $22^{\circ} 36^{\prime} 28^{\prime \prime} \mathrm{N}, 105^{\circ} 52^{\prime} 15^{\prime \prime}$ E, tropical evergreen forest soil associated with Machilus sp. and Dimocarpus sp., deposited in the nematode collection of the University of Jaén, Spain.

\section{Paratypes}

VIETNAM: 4 우, $3 \hat{\jmath} \hat{\jmath}$, in acceptable state of preservation, same data as holotype; $1 \hat{+}, 1 \hat{0}$, in acceptable state of preservation, same locality, deposited in the nematode collection of the Institute of Ecology and Biological Resources, Hanoi, Vietnam; 1 o, same locality, used for SEM.

\section{Description}

\section{Adult}

Moderately slender to slender nematodes of medium to big size, 2.56-3.24 mm long. Body cylindrical, distinctly tapering towards the anterior end, less so towards the posterior end as the caudal region is short and rounded. Habitus curved ventrad after fixation, especially in posterior body region, C-, G- or spiral-shaped. Cuticle 3.0-4.5 $\mu \mathrm{m}$ thick at anterior region, 5-6 $\mu \mathrm{m}$ in mid-body and 8-10 $\mu \mathrm{m}$ on tail; consisting of three layers, especially distinguishable at caudal region: thinner outer layer bearing very fine transverse striation across the entire body, thicker intermediate layer with radial striation, and thin inner layer. Lateral chords 13-21 $\mu \mathrm{m}$ wide at mid-body, occupying about one-sixth (13-18\%) of midbody diameter. Two ventral and two dorsal body pores often present at level of odontostyle-odontophore. Lip region hardly offset from the adjacent body by weak, but perceptible depression, 2.8-3.0 times wider than high and up to one-fourth (17-25\%) of body diameter at neck base; lips (under SEM) mostly amalgamated, but their perioral part distinctly separated by the existence of six radial, interlabial, deep incisures delimiting six perceptible liplets; button-like labial papillae, the inner ones located at the margin of the oral field and surrounded by two or three concentric annuli, whereas the outer papillae, located 
A
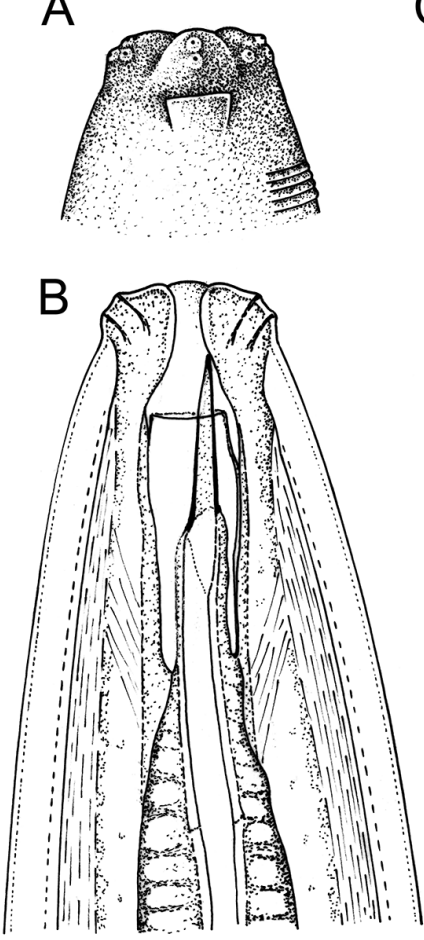

G

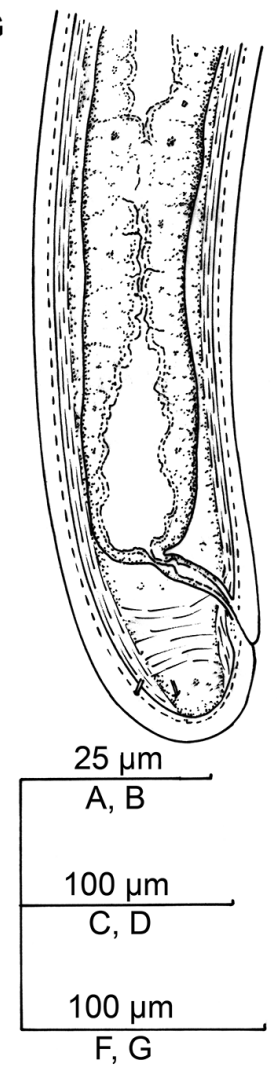

C
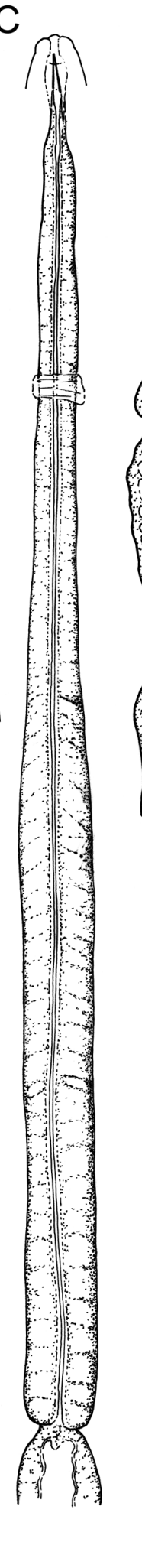

E

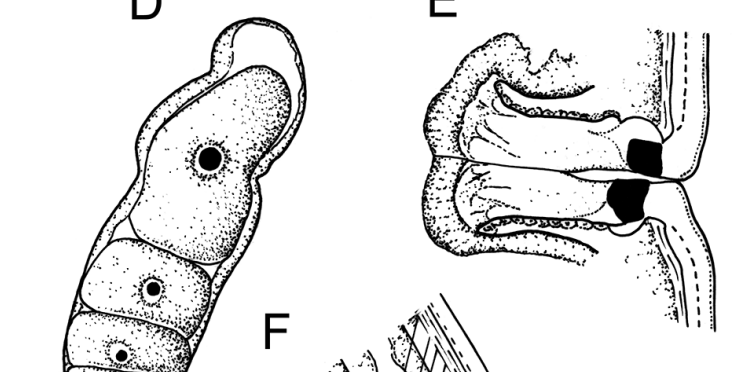

$\mathrm{F}$

$\mathrm{D}$

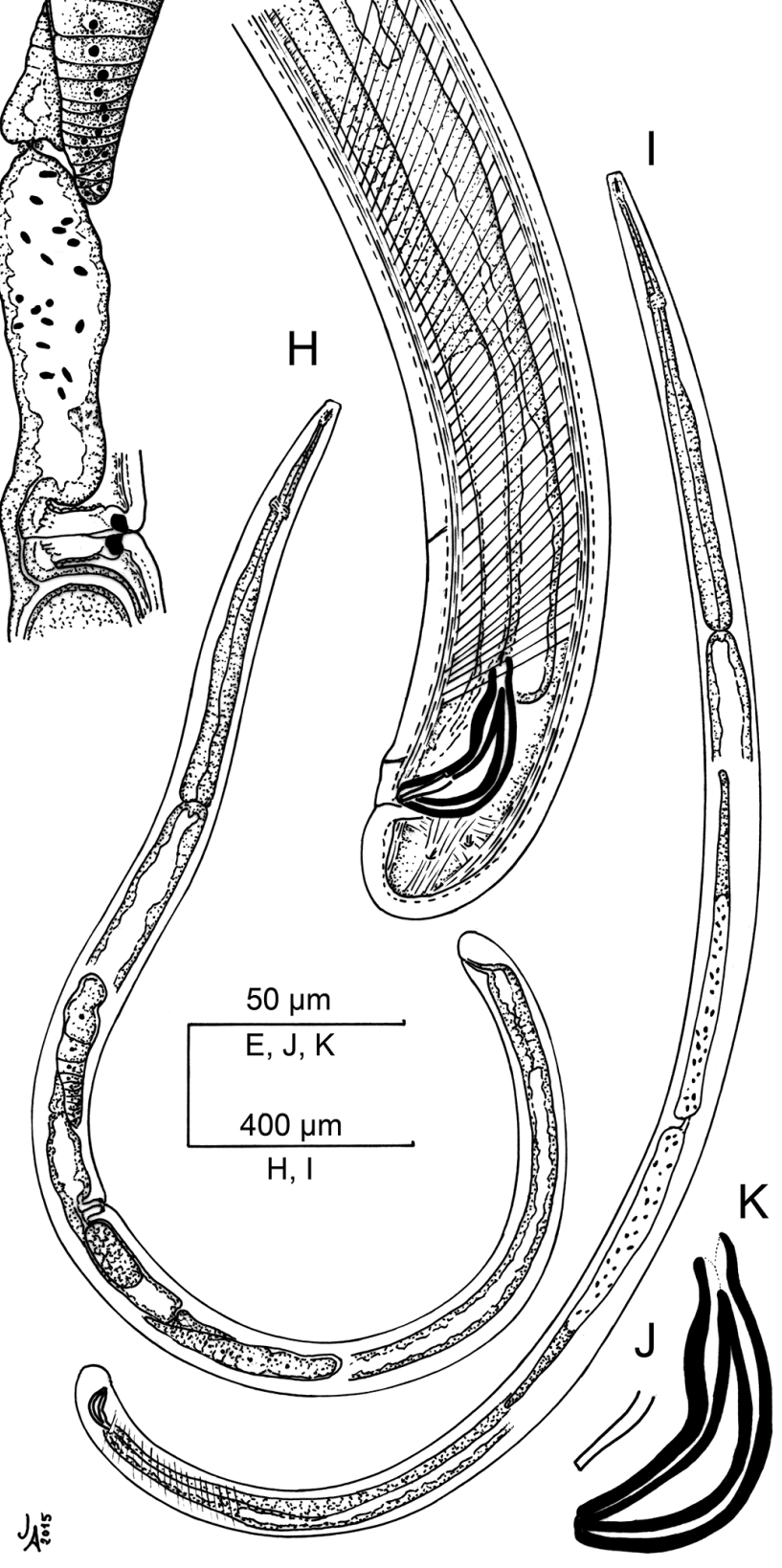

Fig. 1. Sectonema tropicum sp. nov. (Line). A. Lip region in lateral surface view. B. Anterior region in mid-optical level, lateral view. C. Neck region. D. + , anterior genital branch. E. Vagina. F. $\overbrace{}^{\Uparrow}$, posterior body region. G., , posterior body region. H., , entire. I. ${ }^{\wedge}$, entire. J. Lateral guiding piece. K. Spicule. 


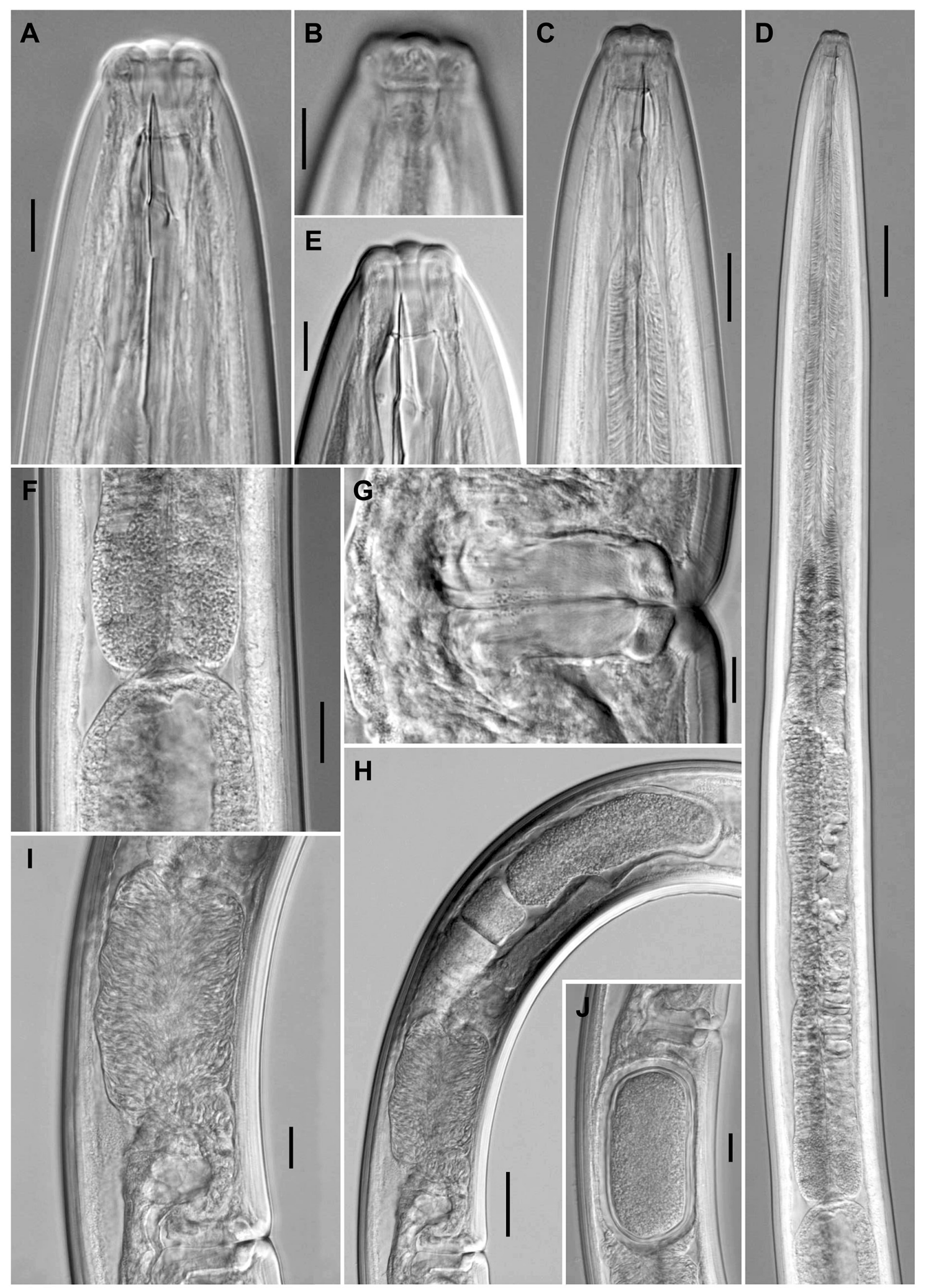

Fig. 2. Sectonema tropicum sp. nov. (LM). A, C, E. Anterior region in lateral, median view. B. Lip region in lateral, surface view. D. Neck region. F. Pharyngo-intestinal junction. G. Vagina. H. \&, anterior genital branch. I. Vagina and anterior uterus containing sperm cells inside. J. Uterine egg. Scale bars: $\mathrm{A}-\mathrm{B}, \mathrm{E}, \mathrm{G}=10 \mu \mathrm{m} ; \mathrm{C}, \mathrm{F}, \mathrm{I}-\mathrm{J}=20 \mu \mathrm{m} ; \mathrm{D}, \mathrm{H}=50 \mu \mathrm{m}$. 
a little behind the inner papillae, are surrounded by only one annulus; cephalic papillae pore- rather than button-like, also surrounded by only one ring-like annulus; oral aperture a dorso-ventral, slightly hexagonal orifice, the lip region hence showing a bi-radial symmetry. Amphid fovea cup-shaped, its opening occupying 9-10 $\mu \mathrm{m}$ or less than one-half (43-49\%) of lip region diameter. Cheilostom nearly cylindrical, without any differentiation. Stomatal protruding structure apparently a reduced odontostyle 6.6-7.1 times longer than wide (see: Remarks), its ventral side 1.0-1.1 times longer than lip region diameter and $0.65-0.83 \%$ of body length. Guiding ring simple, plicate, at $0.8-0.9$ lip region diameters from the anterior end. Odontophore linear, rod-like, 1.7-1.9 times the odontostyle length, somewhat irregular at its base and with (in lateral view) the ventral side slightly longer than the dorsal one (Fig. 2A). Anterior region of pharynx enlarging very gradually; basal expansion 7.1-10.7 times longer than wide, 3.6-5.6 times as long as body diameter, and occupying 52-59\% of total neck length; gland nuclei
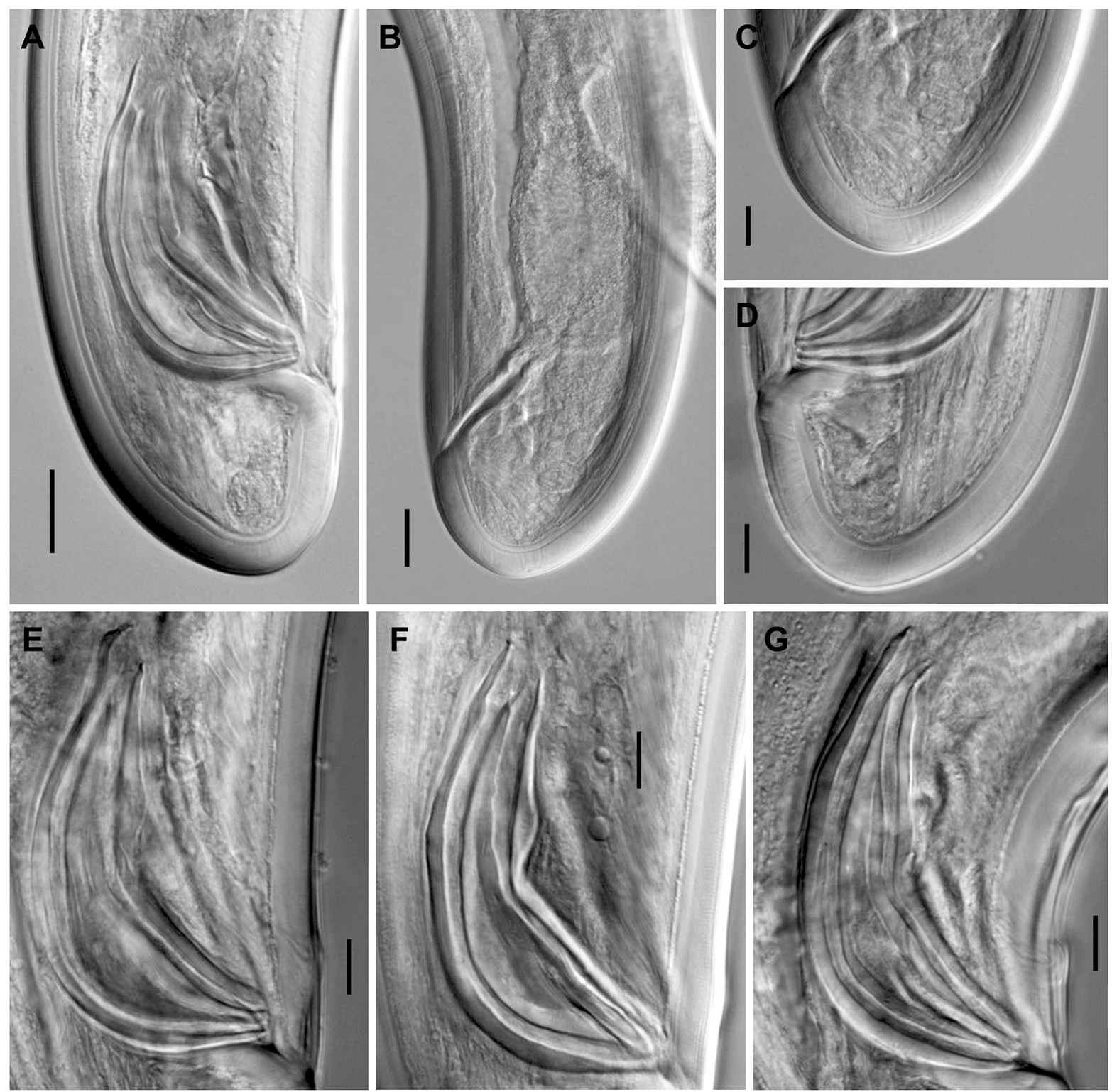

Fig. 3. Sectonema tropicum sp. nov. (LM). A. ${ }^{\lambda}$, posterior body region. B. + , posterior body region. C. $q$, caudal region. D. $\widehat{\jmath}$, caudal region. E-G. Spicules, E-F also showing the lateral guiding piece. Scale bars: $A-B=20 \mu \mathrm{m} ; \mathrm{C}-\mathrm{G}=10 \mu \mathrm{m}$. 
often obscure, located as follows: $\mathrm{DN}=60-62(\mathrm{n}=4) ; \mathrm{S}_{1} \mathrm{~N}_{1}=75(\mathrm{n}=2) ; \mathrm{S}_{1} \mathrm{~N}_{2}=$ obscure; $\mathrm{S}_{2} \mathrm{~N}=$ obscure. Nerve ring located at $182-216 \mu \mathrm{m}$ from anterior end or $25-26 \%$ of total neck length. Cardia rounded conoid, 13-17 × 13-17 $\mu \mathrm{m}$; a weak ring-like structure is present surrounding its junction to pharyngeal base.

\section{Female}

Genital system didelphic-amphidelphic, with almost equally and well developed branches, the anterior $320-442 \mu \mathrm{m}$ or $12-15 \%$ of body length and the posterior $348,440 \mu \mathrm{m}(\mathrm{n}=2)$ or $14,16 \%$ of body length (447, $509 \mu \mathrm{m}$ or $15,17 \%$ bearing one uterine egg inside). Reflexed ovaries well developed, often surpassing the sphincter level, the anterior 182-319 $\mu \mathrm{m}$, the posterior 207-380 $\mu \mathrm{m}$ long; oocytes arranged first in two or more rows, then in a single row. Oviduct 124-174 $\mu \mathrm{m}$ long or 1.1-1.8 times the
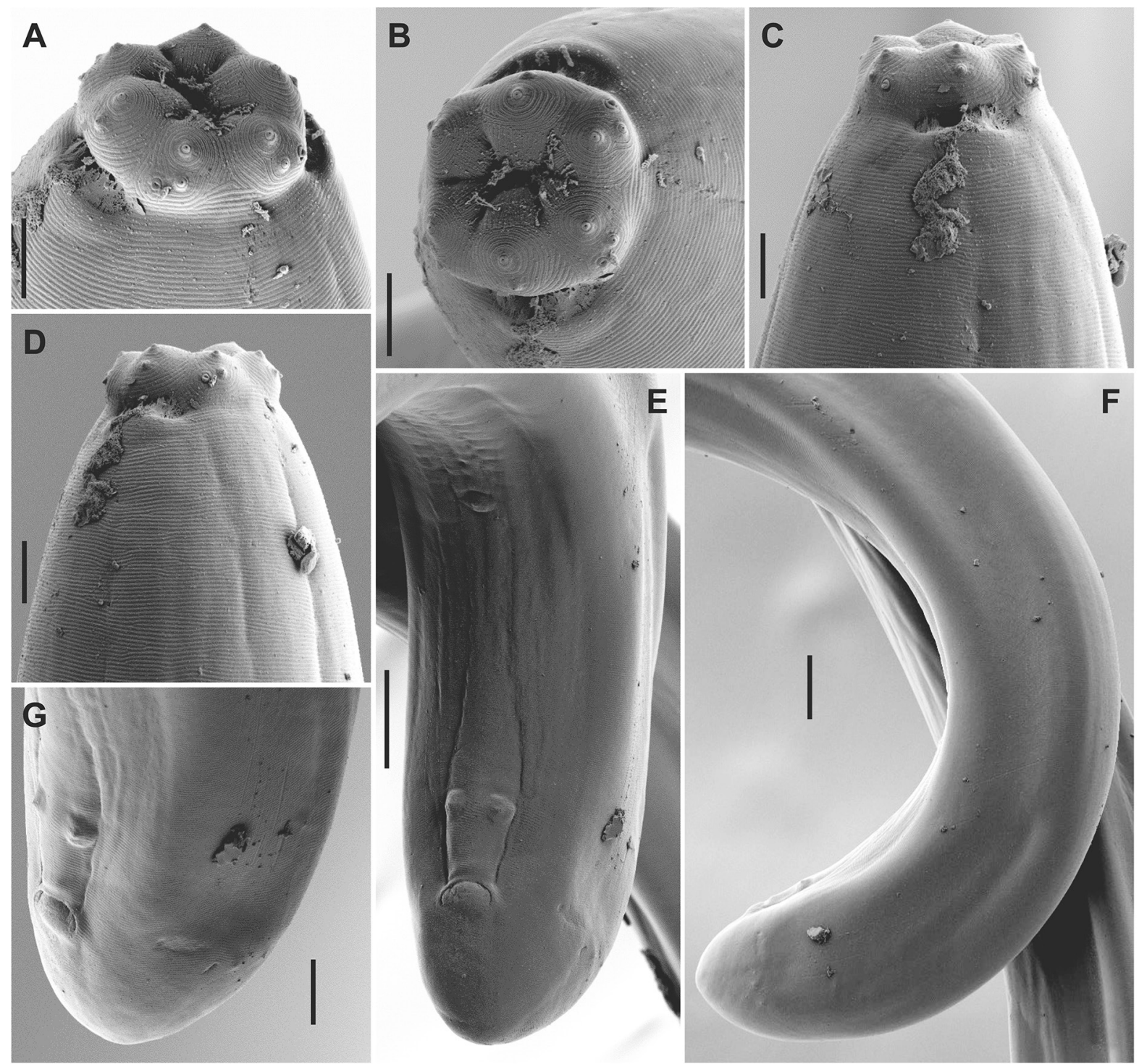

Fig. 4. Sectonema tropicum sp. nov. (SEM, §). A. Lip region in ventral view. B. Lip region in frontal view. C. Lip region in lateral view. D. Lip region in sublateral view. E. Posterior body region in ventral view. F. Posterior body region in lateral view. G. Caudal region in sublateral view. Scale bars: A-D = $5 \mu \mathrm{m} ; \mathrm{E}-\mathrm{F}=20 \mu \mathrm{m} ; \mathrm{G}=10 \mu \mathrm{m}$ 
corresponding body diameter, and consisting of a slender part made of prismatic cells and a moderately developed pars dilatata, with visible lumen and often containing sperm cells inside. Oviduct-uterus junction marked by a sphincter. Uterus a simple, tube-like structure $150-190 \mu \mathrm{m}$ long or 1.2-1.7 times the corresponding body diameter [223, $242 \mu \mathrm{m}(\mathrm{n}=2)$ long or 2.2, 2.5 times the corresponding body diameter, with one uterine egg inside; and $231,240 \mu \mathrm{m}(\mathrm{n}=1)$ long, with two uterine eggs], always containing abundant sperm cells inside. Vagina extending inwards $52-57 \mu \mathrm{m}$ or one-half to foursevenths (48-57\%) of body diameter: pars proximalis $33-43 \times 23-28 \mu \mathrm{m}$, with somewhat sigmoid walls surrounded by weak musculature; pars refringens with two trapezoidal pieces measuring (in optical section) $13-16 \times 7-9 \mu \mathrm{m}$ and with a combined width of 24-28 $\mu \mathrm{m}$; pars distalis 5.5-7.0 $\mu \mathrm{m}$ long. Vulva a nearly equatorial transverse slit. Prerectum $2.0-2.4$, rectum $0.7-1.0$ anal body diameters long. Tail short and rounded; two pairs of caudal pores, sublateral and close together.

\section{Male}

Genital system diorchic, with opposite testes. In addition to the ad-cloacal pair, situated at $18-21 \mu \mathrm{m}$ from cloacal aperture, one weakly developed ventromedian supplement, lying out the range of retracted spicules and located at $80-131 \mu \mathrm{m}$ from the ad-cloacal pair. Spicules distinctly robust and massive, especially in its posterior half, 3.6-4.2 times its maximum width, 1.4-1.6 times the body diameter at level of the cloacal aperture: dorsal contour regularly convex, ventral contour slightly concave, with distinct hump and hollow; curvature $121-124^{\circ}$; head occupying $11-16 \%$ of spicule total length, its dorsal side visibly curved at its anterior end and longer than the ventral one, which is shorter and almost straight; median piece 5.4-6.2 times longer than wide, occupying 51-59\% of spicule maximum width, reaching the posterior tip; posterior end 7-8 $\mu \mathrm{m}$ wide. Lateral guiding pieces $23-29 \mu \mathrm{m}$ long, 5.37.1 times longer than wide. Prerectum 3.2-4.6, cloaca 0.9-1.3 times the corresponding body width long. Cloacal aperture, as seen under SEM, a curved anteriad, transverse slit. Tail similar to that of female; caudal pores two pairs, one lateral, another subdorsal.

\section{Relationships}

In having a long stomatal protruding structure (20-21 $\mu \mathrm{m}$ at its ventral side) and short ( $c^{\prime}$ up to 1.0$)$ and rounded tail, S. tropicum sp. nov. is morphologically very similar to $S$. demani Altherr, 1965, S. heynsi Altherr, 1968, S. rotundicauda Goodey, 1951, S. septentrionale Peña-Santiago \& Álvarez-Ortega, 2015 and S. sica Clark, 1964, but it can be distinguished from all of them in its smaller general size (body length 2.56-3.24 mm, neck 730-834 $\mu \mathrm{m}$ long vs more than $5 \mathrm{~mm}$, more than $1000 \mu \mathrm{m}$ long, respectively), nearly continuous lip region (vs offset by a more or less deep constriction) and stomatal protruding structure of different nature (a reduced odontostyle vs a mural tooth; see Remarks). Besides, the new species differs from $S$. demani (see recent re-description by Peña-Santiago \& Álvarez-Ortega $2014 \mathrm{~b}$ ) in its less slender ( $a=21-36$ vs $a=48-56$ ) body, narrower (19-21 vs 27-28 $\mu \mathrm{m}$ broad) lip region, shorter pharyngeal expansion (occupying $52-59$ vs $68-69 \%$ of total neck length), shorter female tail (32-39 vs 51-55 $\mu \mathrm{m}, c^{\prime}=0.5-0.6$ vs $\left.c^{\prime}=0.7-0.8\right)$, and male present (vs absent). It differs from $S$. heynsi (see recent re-description by Peña-Santiago \& Álvarez-Ortega 2014b) in its narrower (19-21 vs $28 \mu \mathrm{m}$ broad) lip region, circumoral area lacking (vs bearing) cilia- or setae-like structures, shorter pharyngeal expansion (occupying $52-59$ vs $68 \%$ of total neck length), shorter (32-39 vs $54 \mu \mathrm{m}, c^{\prime}=$ $0.5-0.6$ vs $\left.c^{\prime}=0.7\right)$ female tail, and male present (vs absent). It differs from $S$. rotundicauda in its less slender ( $a=21-36$ vs $a=80$ ) body, narrower (19-21 vs about $28 \mu \mathrm{m}$ broad) lip region, shorter (31-40 vs $64 \mu \mathrm{m}$ ) male tail, fewer (one vs four) ventromedian supplements, and shorter (91-97 vs about $155 \mu \mathrm{m})$ spicules. It differs from $S$. septentrionale in its less slender ( $a=21-36$ vs $a=47-64)$ body, narrower (19-21 vs 25-29 $\mu \mathrm{m}$ broad) lip region, shorter (occupying 52-59 vs $60-73 \%$ of total neck length) pharyngeal expansion, uterus simple (vs tripartite) and shorter (150-242 $\mu \mathrm{m}$ or 1.2-2.5 times the body diameter vs 370-493 $\mu \mathrm{m}$ or 2.9-4.3 times the corresponding body diameter), shorter (31-40 vs 40-62 $\mu \mathrm{m}, c^{\prime}=0.5-0.6$ vs $c^{\prime}=0.6-0.8$ ) tail, fewer (one vs 5-11) ventromedian supplements, and shorter (91-97 vs 100-145 $\mu \mathrm{m}$ ) spicules. Finally, it differs from S. sica in its narrower (19-21 vs about $24 \mu \mathrm{m}$ 
Table 1. Morphometrics of Sectonema tropicum sp. nov. Measurements in $\mu \mathrm{m}$ (except $\mathrm{L}$, in $\mathrm{mm}$ ), and in the form: mean \pm standard deviation (range).

\begin{tabular}{|c|c|c|c|}
\hline \multirow{3}{*}{ Character } & \multicolumn{3}{|c|}{ Cao Bằng Province (Pia Oac Natural Reserve) } \\
\hline & \multirow{2}{*}{$\begin{array}{c}\text { Holotype } \\
+ \\
+ \\
\end{array}$} & \multicolumn{2}{|c|}{ Paratypes } \\
\hline & & $\mathbf{5}$ 우 & $5 \hat{\jmath}$ \\
\hline $\mathbf{L}$ & 3.04 & $2.81 \pm 0.19(2.57-3.05)$ & $2.87 \pm 0.31(2.56-3.24)$ \\
\hline $\mathbf{a}$ & 31 & $24.9 \pm 4.7(21-31)$ & $29.0 \pm 5.9(23-36)$ \\
\hline b & $?$ & $3.7 \pm 0.2(3.4-3.9)$ & $3.7 \pm 0.3(3.4-3.9)$ \\
\hline c & 87 & $79.4 \pm 6.5(70-88)$ & $81.3 \pm 7.0(73-91)$ \\
\hline c' & 0.6 & $0.6 \pm 0.0(0.5-0.6)$ & $0.6 \pm 0.1(0.5-0.6)$ \\
\hline $\mathbf{V}$ & 50 & $50.6 \pm 1.5(48-52)$ & - \\
\hline Lip region diam. & 20 & $20.1 \pm 0.6(20-21)$ & $20.1 \pm 0.6(19-21)$ \\
\hline Odontostyle length at ventral side & 21 & $20.6 \pm 0.6(20-21)$ & $20.7 \pm 0.5(20-21)$ \\
\hline Odontostyle length at dorsal side & 23 & $22.5 \pm 0.5(22-23)$ & $22.5 \pm 0.4(22-23)$ \\
\hline Odontophore length & 36 & $36.0 \pm 1.0(35-38)$ & $35.3 \pm 0.7(34-36)$ \\
\hline Guiding ring from ant. end & 17 & $17.4 \pm 0.6(17-18)$ & $18.1 \pm 0.1(18-18)$ \\
\hline Neck length & $?$ & $764 \pm 23(730-790)$ & $801 \pm 49(745-834)$ \\
\hline Pharyngeal expansion length & $?$ & $427 \pm 29(403-468)$ & $448 \pm 19(436-470)$ \\
\hline Diam. at neck base & 99 & $103 \pm 12(91-116)$ & $95 \pm 11(84-111)$ \\
\hline at midbody & 99 & $114 \pm 14(98-130)$ & $101 \pm 12(90-118)$ \\
\hline at anus & 60 & $64.4 \pm 4.5(61-72)$ & $61.2 \pm 2.1(60-65)$ \\
\hline Prerectum length & 143 & $136 \pm 9(126-150)$ & $228 \pm 37(189-277)$ \\
\hline Rectum/cloacla length & 54 & $53.8 \pm 3.0(52-59)$ & $66.3 \pm 8.8(53-77)$ \\
\hline Tail length & 35 & $35.5 \pm 3.3(32-39)$ & $35.4 \pm 3.0(31-40)$ \\
\hline Spicule length & - & - & $92.5 \pm 2.6(91-97)$ \\
\hline Ventromedian supplements & - & - & $1 \pm 0(1-1)$ \\
\hline
\end{tabular}

broad) lip region, shorter (occupying 52-59\% vs two-thirds of total neck length) pharyngeal expansion, more posterior $(V=48-52$ vs $V=40)$ vulva, shorter $\left(32-39\right.$ vs $54 \mu \mathrm{m}, c^{\prime}=0.5-0.6$ vs $\left.c^{\prime}=0.7\right)$ female tail, and male present (vs absent).

Moreover, in having a lip region nearly continuous with the adjacent body, the new species resembles S. mucrodens Siddiqi, 1984 and S. truxum Siddiqi, 1984, but it can be easily distinguished from these by the more anterior position of the stomatal protruding structure (its anterior tip in front of the level of guiding ring, just behind the base of lip region vs its anterior tip distinctly behind the level of guiding ring, far from the lip region base) and pars refringens vaginae well (vs faintly) developed. Moreover, it differs from S. mucrodens by its shorter (730-834 vs 1086-1157 $\mu \mathrm{m}$ ) neck, shorter (occupying 52-59 vs $69 \%$ of total neck length) pharyngeal expansion, shorter $\left(32-39 \mu \mathrm{m}, c^{\prime}=0.5-0.6 \mathrm{vs} 44-50 \mu \mathrm{m}, c^{\prime}=0.7\right)$ female tail, and male present (vs absent). It differs from $S$. truxum in its narrower (19-21 vs $24 \mu \mathrm{m}$ broad) lip region, shorter (730-834 vs $837-1070 \mu \mathrm{m})$ neck, more anterior $(V=48-52$ vs $V=54-56)$ vulva, and male present (vs absent).

\section{Molecular characterisation}

Two sequences of the D2-D3 28S rRNA gene were obtained from one female and one male. Both sequences are very similar (99\%) and differ by two nucleotides only. The evolutionary relationships of the new species with representatives of the order Dorylaimida are presented in Figs 5-6. The two S. tropicum sp. nov. sequences are clustered together with other available sequences of Sectonema representatives and form a highly supported clade together with members of the genus Metaporcelaimus, thus confirming previous results (Álvarez-Ortega et al. 2013a, b). 


\section{Remarks}

The nature of the stomatal protruding structure in the new species is difficult to interpret and deserves further explanation. The specimens examined bear a reduced odontostyle (comparable to that described in the type species $S$. ventrale Thone, 1930; see recent description by Peña-Santiago \& Álvarez-Ortega

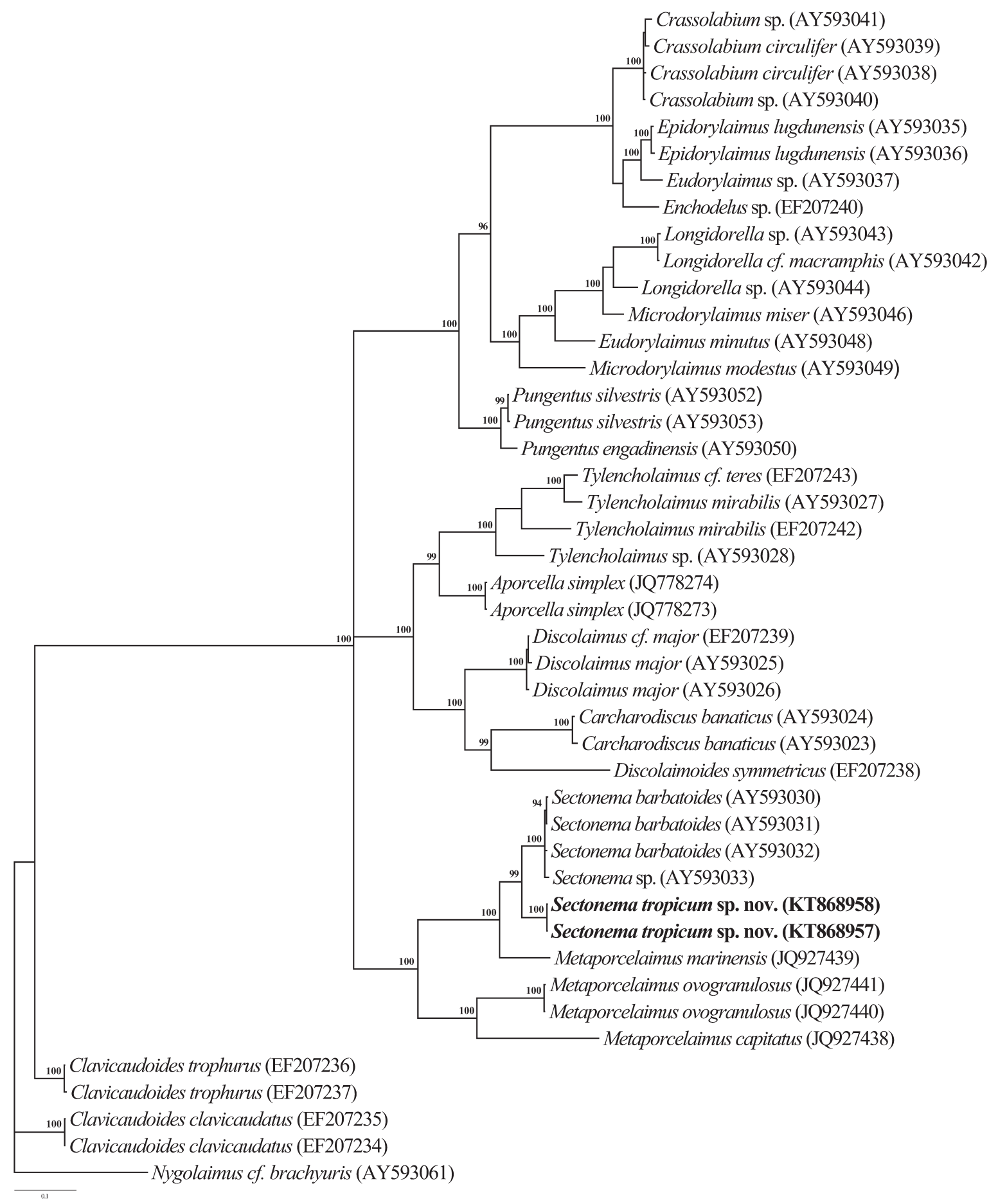

Fig. 5. Bayesian 50\% majority rule consensus trees as inferred from D2-D3 expansion segments of $28 \mathrm{~S}$ rRNA gene sequence alignments under the GTR + I + G model. Posterior probabilities are given for appropriate clades. Newly obtained sequences are indicated by bold letters. 
2014a) rather than a mural tooth as the base of its dorsal side is visibly sclerotized and seems to join the dorsal stomatal wall (vs dorsal side not scletorized at the base, somewhat sigmoid and not joining the dorsal stomatal wall). Nonetheless, some doubt persists in this matter.

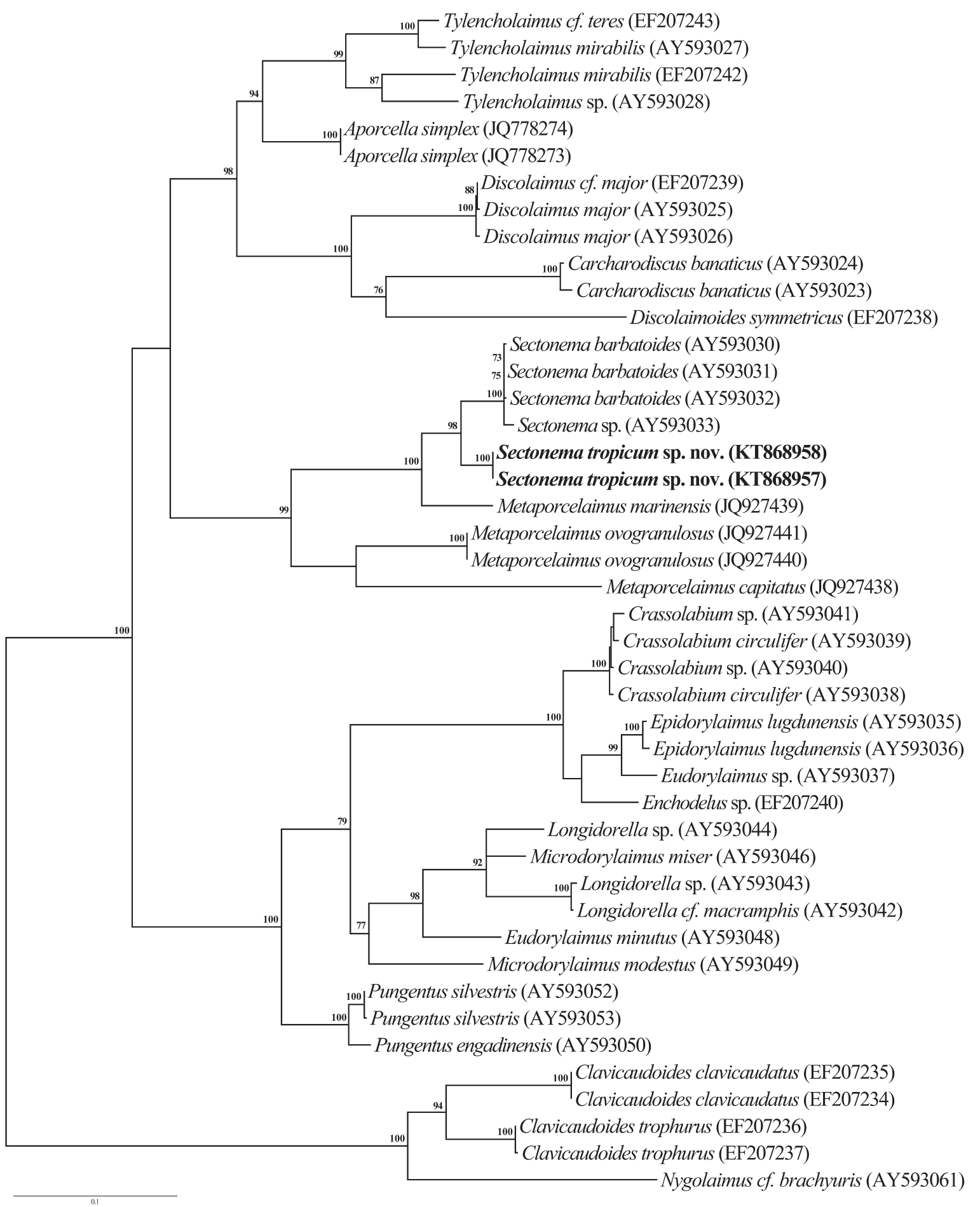

Fig. 6. Maximum Likelihood tree as inferred from D2-D3 expansion segments of 28S rRNA gene sequence alignments under the GTR $+\mathrm{I}+\mathrm{G}$ model. Bootstrap values are given for appropriate clades. Newly obtained sequences are indicated by bold letters. 


\section{Sectonema vietnamense sp. nov. urn:lsid:zoobank.org:act:AF58451E-D7A7-4E49-8A18-9F3998EF4A87}

Figs 7-9, Table 2

\section{Diagnosis}

The new species is characterized by a slender $(a=33-49) 2.71-4.25 \mathrm{~mm}$ long body, lip region offset by depression and 14-16 $\mu \mathrm{m}$ broad, odontostyle 8-9 $\mu \mathrm{m}$ long at its ventral side, 716-918 $\mu \mathrm{m}$ long neck, pharyngeal expansion $463-618 \mu \mathrm{m}$ long or $63-67 \%$ of total neck length, uterus simple and 209-242 $\mu \mathrm{m}$ long or 2.5-2.9 times the corresponding body diameter, pars refringens vaginae absent, $V=54$, short $\left(36 \mu \mathrm{m}, c=105, c^{\prime}=0.7\right)$ and rounded tail in female and slightly more conoid (34-39 $\mu \mathrm{m}, c=70$ $\left.115, c^{\prime}=0.6-0.8\right)$ in male, 59-75 $\mu \mathrm{m}$ long spicules, and three or four irregularly spaced ventromedian supplements bearing hiatus.

\section{Etymology}

The specific epithet refers to the geographical origin of the species.

\section{Type material examined}

\section{Holotype}

VIETNAM: + , in good state of preservation, Northern Vietnam, Cuc Phuong National Park, pristine tropical forest, deposited in the nematode collection of the University of Jaén, Spain.

\section{Paratypes}

VIETNAM: $4 \hat{\partial} \partial^{\lambda}, 3$ juvs, in good state of preservation, same data as holotype; $1 \hat{\partial}$, in good state of preservation, same locality, deposited in the nematode collection of the Institute of Ecology and Biological Resources, Hanoi, Vietnam; $1 \overbrace{}^{\lambda}, 1$ juv., same locality, used for SEM.

\section{Other material examined}

VIETNAM: $2 \precsim \widehat{\jmath}$, in acceptable state of preservation, Northern Vietnam, Thái Bình province, intensively cultured field, deposited in the nematode collection of the University of Jaén, Spain.

\section{Description (type population)}

\section{Adult}

Very slender nematodes of big size, 3.13-4.25 mm long. Body cylindrical, distinctly tapering towards the anterior end, less so towards the posterior one as the caudal region is rounded. Habitus regularly curved ventrad after fixation, to a more or less open C, occasionally more curved at posterior body region. Cuticle 2.0-2.5 $\mu \mathrm{m}$ thick at anterior region, 3.0-4.5 $\mu \mathrm{m}$ in mid-body and $8-10 \mu \mathrm{m}$ on tail; consisting of three layers especially distinguishable at caudal region: thinner outer layer bearing very fine transverse striation through the entire body, thicker intermediate layer with radial striation, and thin inner layer. Lateral chords $6-12 \mu \mathrm{m}$ wide at mid-body, occupying up to one-sixth $(8-15 \%)$ of mid-body diameter. Two ventral and two dorsal body pores often present at level of stoma, and four distinct lateral pores 6-20 $\mu \mathrm{m}$ apart visible behind the amphid fovea. Lip region nearly continuous (a shallow depression is, however, often perceptible), weakly angular, visibly narrower than adjacent body, 2.1-2.3 times wider than high and about one-fifth (18-23\%) of body diameter at neck base; it appears (under SEM) marked by radial (oral field) or longitudinal (remaining lip region) incisures, with amalgamated lips and protruding, pore-like labial and cephalic papillae, all of them surrounded by a ring-like annulus, and the inner labial papillae visibly larger than the outer ones; oral field perceptibly hexagonal, oral aperture a dorso-ventral slit, the lip region hence showing a bi-radial symmetry. Cupshaped amphid fovea, its opening at level of cephalic depression and occupying $10-11 \mu \mathrm{m}$ or $68-72 \%$ of lip region diameter. Nearly cylindrical cheilostom, without differentiation. Odontostyle comparatively 


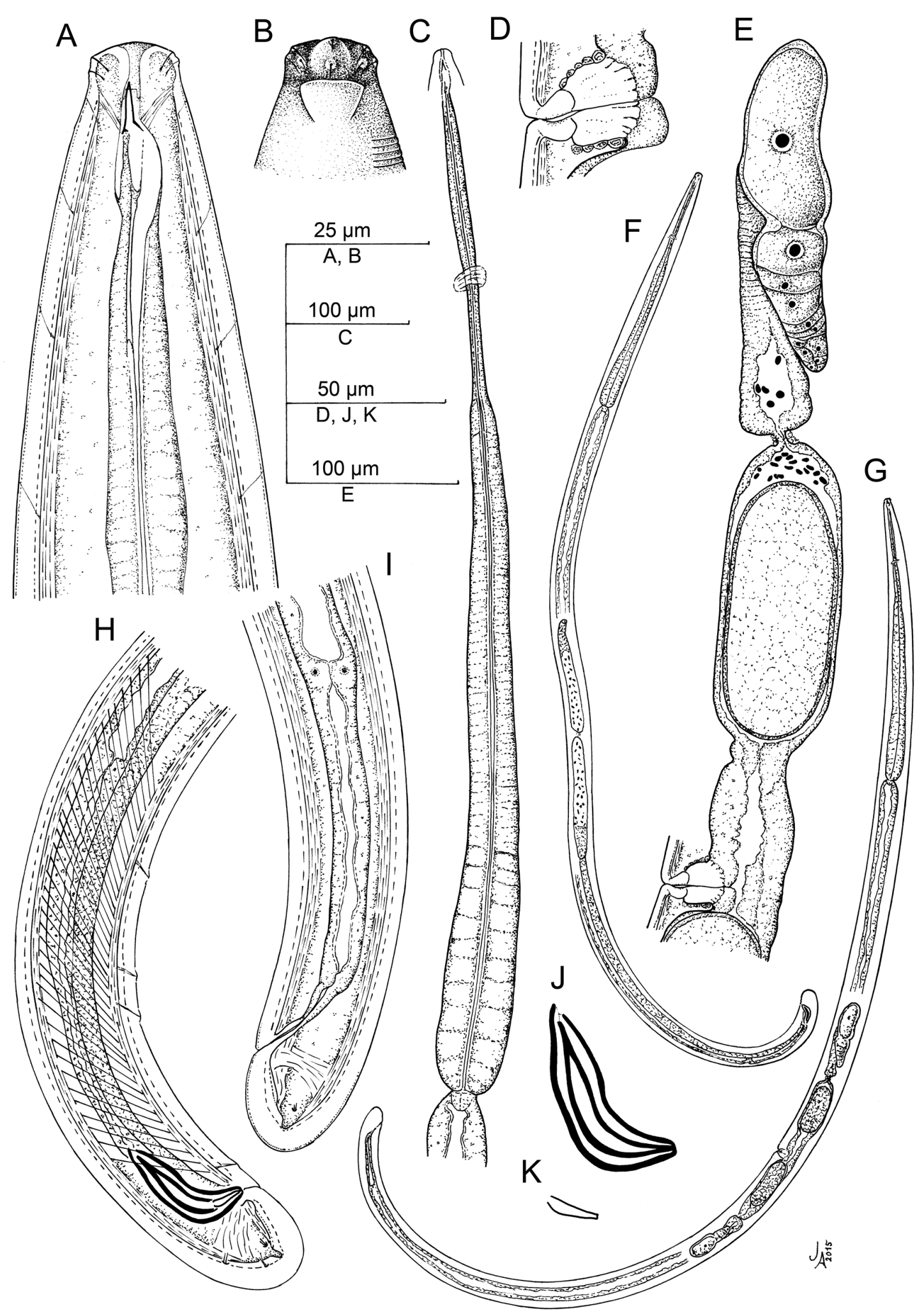

Fig. 7. Sectonema vietnamense sp. nov. (Line). A. Anterior region in median, lateral view. B. Lip region in surface, lateral view. C. Neck region. D. Vagina. E. o, anterior genital branch. F. $ð$, entire. G. $ᄋ$, entire. H. $\stackrel{\jmath}{\text { }}$, posterior body region. I. + , posterior body region. J. Spicule. K. Lateral guiding piece. 
short and occupying the whole stomatal lumen, its ventral side 0.5-0.6 times longer than lip region diameter and $0.20-0.29 \%$ of body length. Guiding ring simple, somewhat plicate, at 0.5 times the lip region diameter from anterior end. Odontophore linear, rod-like, 3.7-4.2 times the odontostyle length. Tripartite pharynx, consisting of an anteriorly thickened section behind the odontophore base, a perceptible narrower intermediate section with the nerve ring surrounding it, which enlarges very gradually into the basal expansion 9.9-15.0 times longer than wide, 6.7-7.3 times longer than body
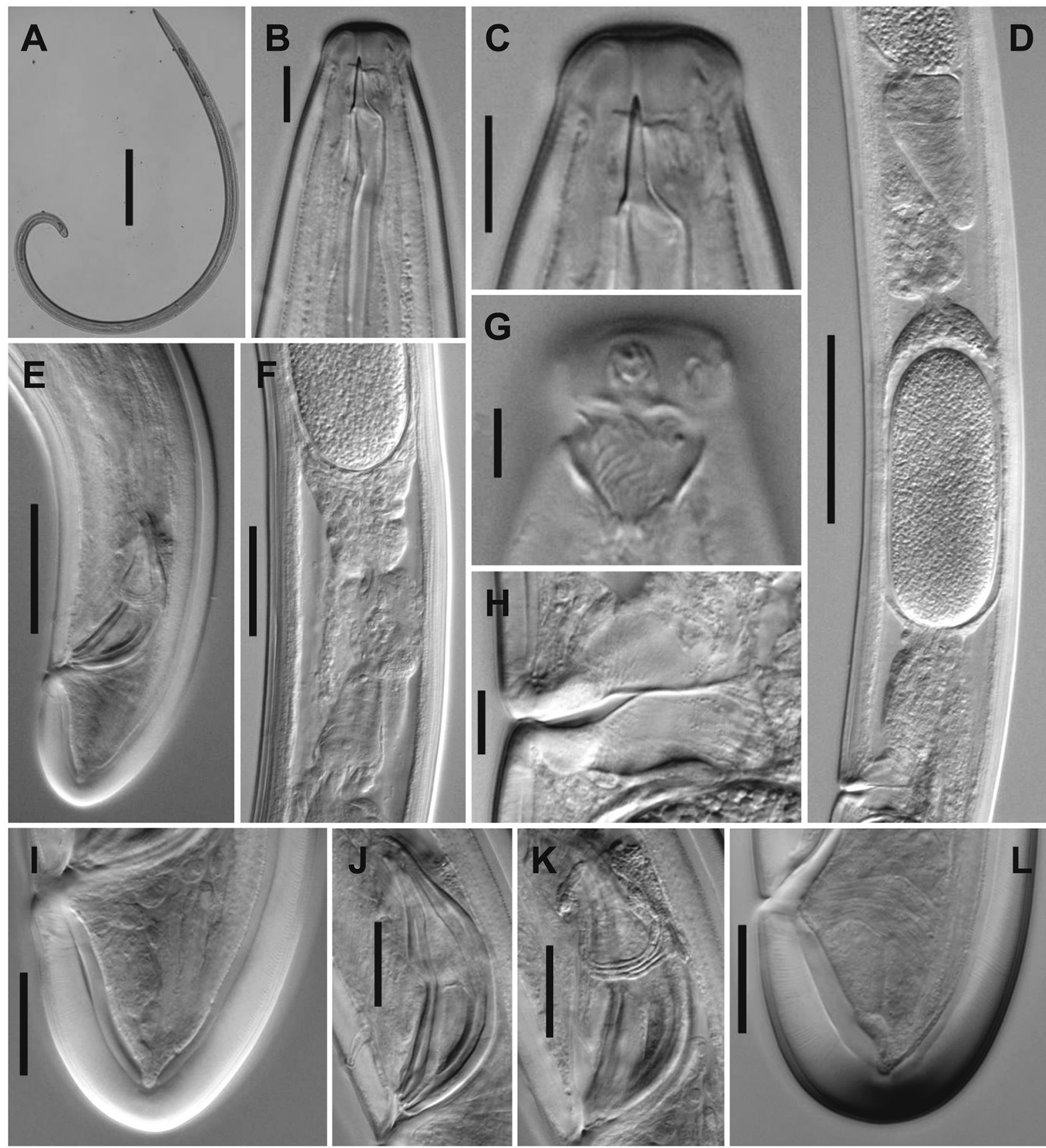

Fig. 8. Sectonema vietnamense sp. nov. (LM, type population). A. $\partial^{\lambda}$, entire. B-C. Anterior region in

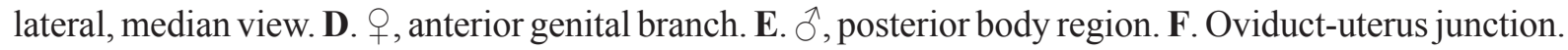
G. Lip region in lateral, surface view. H. Vagina. I. $\widehat{\jmath}$, caudal region. J-K. Spicules. L. ㅇ, caudal region. Scale bars: $A=500 \mu \mathrm{m} ; \mathrm{B}-\mathrm{C}, \mathrm{H}=10 \mu \mathrm{m} ; \mathrm{D}=100 \mu \mathrm{m} ; \mathrm{E}-\mathrm{F}=50 \mu \mathrm{m} ; \mathrm{G}=5 \mu \mathrm{m} ; \mathrm{I}-\mathrm{L}=20 \mu \mathrm{m}$. 
diameter and occupying $63-67 \%$ of total neck length; gland nuclei mostly obscure, only $\mathrm{S}_{2} \mathrm{~N}$ are visible, at $77-78 \%(\mathrm{n}=3)$ of total neck length. Nerve ring located at $147-178 \mu \mathrm{m}$ from anterior end or $19-22 \%$ of total neck length. Cardia rounded conoid, $15-19 \times 12-17 \mu \mathrm{m}$; a ring-like structure is present surrounding its junction to pharyngeal base.

\section{Female}

Genital system didelphic-amphidelphic, with almost equally and well developed branches, the anterior $473 \mu \mathrm{m}$ long or $13 \%$ of body length and the posterior $387 \mu \mathrm{m}$ long or $10 \%$ of body length, each branch bearing one uterine egg. Moderately sized ovaries, not surpassing the sphincter level, the anterior $191 \mu \mathrm{m}$, the posterior $141 \mu \mathrm{m}$ long; oocytes arranged first in two or more rows, then in a single row. Oviduct 117, $142 \mu \mathrm{m}$ long or 1.4, 1.7 times the corresponding body diameter, and consisting of a slender part made of prismatic cells and a well developed pars dilatata with wide lumen and sperm cells inside. Oviduct-uterus junction marked by a sphincter. Uterus a simple, tube-like structure 209, $242 \mu \mathrm{m}$ long or 2.5, 2.9 times the corresponding body diameter, containing abundant sperm cells and one uterine egg. Vagina extending inwards $36 \mu \mathrm{m}$ or about three-sevenths (44\%) of body diameter: pars proximalis $23 \times$ $28 \mu \mathrm{m}$, somewhat sigmoid walls and surrounded by weak musculature; pars refringens absent; pars
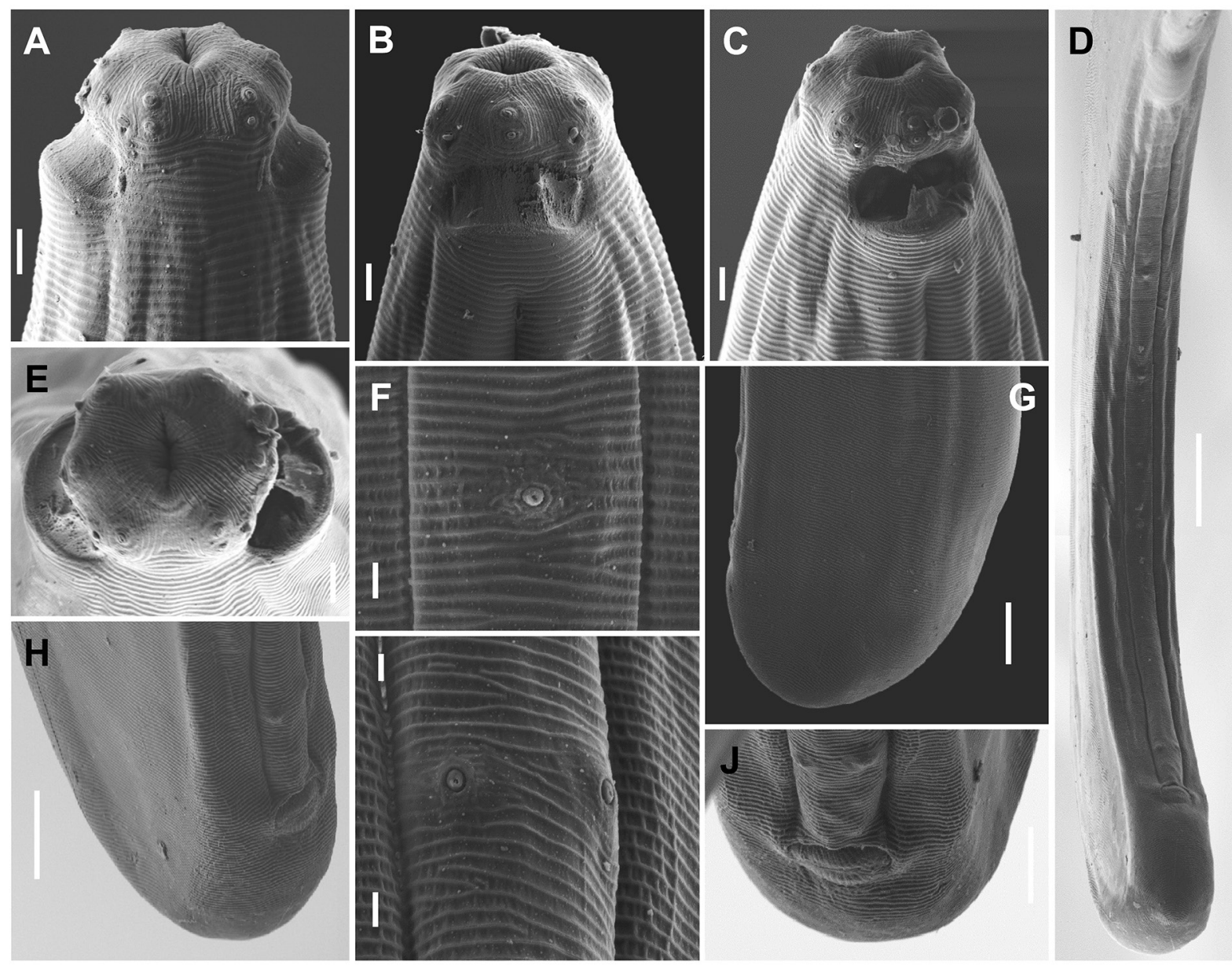

Fig. 9. Sectonema vietnamense sp. nov. $(\mathrm{SEM}, \mathrm{A}=$ juvenile and $\mathrm{B}-\mathrm{J}=\widehat{\AA})$. A. Lip region in ventral view. B-C. Lip region in lateral view. D. Posterior body region in ventral view. E. Lip region in frontal view. F. Detail of a ventromedian supplement. G. Caudal region in lateral view. H. Caudal region in subventral view. I. Detail of the ad-cloacal pair of supplements. J. Caudal region in ventral view. Scale bars $=\mathrm{A}-\mathrm{C}, \mathrm{E}=2 \mu \mathrm{m} ; \mathrm{D}=20 \mu \mathrm{m} ; \mathrm{F}, \mathrm{I}=1 \mu \mathrm{m} ; \mathrm{G}-\mathrm{H}=10 \mu \mathrm{m} ; \mathrm{J}=5 \mu \mathrm{m}$. 
Table 2. Morphometrics of Sectonema vietnamense sp. nov. Measurements in $\mu \mathrm{m}$ (except $\mathrm{L}$, in $\mathrm{mm}$ ), and in the form: mean \pm standard deviation (range).

\begin{tabular}{|c|c|c|c|}
\hline \multirow[b]{2}{*}{ Character } & \multicolumn{2}{|c|}{ Cuc Phuong National Park } & \multirow{2}{*}{$\begin{array}{c}\text { Thái Bình Province } \\
2 \hat{\circ}{ }^{\lambda}\end{array}$} \\
\hline & $\begin{array}{c}\text { Holotype } \\
+ \\
+\end{array}$ & $\begin{array}{c}\text { Paratypes } \\
60 \hat{\diamond}{ }^{\lambda}\end{array}$ & \\
\hline $\mathbf{L}$ & 3.79 & $3.57 \pm 0.49(3.13-4.25)$ & $3.02,2.71$ \\
\hline $\mathbf{a}$ & 46 & $45.9 \pm 3.0(41-49)$ & 35,33 \\
\hline b & 4.6 & $4.5 \pm 0.2(4.3-4.7)$ & ? \\
\hline c & 105 & $96.9 \pm 11.4(86-115)$ & 83,70 \\
\hline c' & 0.7 & $0.7 \pm 0.1(0.6-0.8)$ & $0.8,0.7$ \\
\hline $\mathbf{V}$ & 54 & - & - \\
\hline Lip region diam. & 14 & $14.9 \pm 0.5(14-16)$ & $16(n=2)$ \\
\hline Odontostyle length at ventral side & 9 & $8.8 \pm 0.3(8-9)$ & $9(\mathrm{n}=2)$ \\
\hline Odontostyle length at dorsal side & 10 & $9.5 \pm 0.2(9-10)$ & $10(\mathrm{n}=2)$ \\
\hline Odontophore length & 32 & $34.2 \pm 1.3(33-36)$ & $33(n=2)$ \\
\hline Guiding ring from ant. end & 7 & $7.3 \pm 0.6(7-8)$ & $9(\mathrm{n}=2)$ \\
\hline Neck length & 820 & $790 \pm 84(716-918)$ & $?$ \\
\hline Pharyngeal expansion length & 534 & $521 \pm 65(463-618)$ & $?$ \\
\hline Diam. at neck base & $?$ & $72.0 \pm 8.6(63-85)$ & 80,74 \\
\hline at midbody & 82 & $77.7 \pm 8.3(68-89)$ & 87,82 \\
\hline at anus & 50 & $50.6 \pm 4.3(46-58)$ & 48,55 \\
\hline Prerectum length & 149 & $237 \pm 40(210-297)$ & $199, ?$ \\
\hline Rectum/cloaca length & 45 & $58.8 \pm 9.3(47-71)$ & 66,62 \\
\hline Tail length & 36 & $36.8 \pm 1.8(34-39)$ & 36,38 \\
\hline Spicule length & - & $67.7 \pm 5.3(59-75)$ & 73,70 \\
\hline Ventromedian supplements & - & $3.7 \pm 0.5(3-4)$ & $4(n=2)$ \\
\hline
\end{tabular}

distalis well developed, $15 \mu \mathrm{m}$ long. Vulva a post-equatorial transverse slit. Prerectum 3.0, rectum 0.9 anal body diameters long. Short and rounded tail, its inner core with a finger-like projection at tail end; two pairs of caudal pores, one sub-lateral, another sub-dorsal.

\section{Male}

Genital system diorchic, with opposite testes. In addition to the ad-cloacal pair, situated at 14-19 $\mu \mathrm{m}$ from cloacal aperture, there is a series of three or four irregularly spaced, 15-48 $\mu \mathrm{m}$ apart, ventromedian supplements, the posteriormost of which lying out the range of retracted spicules, at 76-91 $\mu \mathrm{m}$ from the ad-cloacal pair. Spicule robust and massive, especially in its posterior half, 3.6-4.6 times its maximum width, 1.3-1.4 times the body diameter at level of the cloacal aperture: dorsal contour regularly convex, ventral contour slightly concave, with distinct hump and hollow; curvature 125-136 $6^{\circ}$, head occupying $13-19 \%$ of spicule total length, its dorsal contour distinct curved at its anterior end and longer than the ventral one, which is short and almost straight; median piece 5.9-7.1 times longer than wide, occupying $52-65 \%$ of spicule maximum width, reaching the posterior tip; posterior end 6-7 $\mu \mathrm{m}$ wide. Lateral guiding pieces 15-17 $\mu \mathrm{m}$ long, 5.3-6.5 times longer than wide. Prerectum 4.3-5.7, cloaca 1.0-1.3 times the corresponding body width long. Rectal glands and their ducts ( $c f$. Coomans \& Loof 1986) very well perceptible (Fig. 8K). Cloacal aperture, as seen under SEM, a somewhat curved anteriad, transverse slit; the two supplements of the precloacal pair distinctly separated. Tail a little more conoid than that of female; two pairs of caudal pores, one almost lateral, another sub-dorsal. 


\section{Relationships}

The new species is easily distinguishable from its congeners in the unique combination of these features: narrow and nearly continuous lip region, very short odontostyle, absence of pars refringens vaginae and short and rounded tail. Nonetheless, it resembles S. barbatum Heyns, 1965 in its general morphology, but it can be distinguished from this because of its oral field lacking any setae-like structure (vs bearing numerous short forwardly pointing setae), narrower (14-16 vs about $22 \mu \mathrm{m}$ broad) lip region, shorter (8-9 vs $16 \mu \mathrm{m})$ odontostyle, pars refringens vaginae absent (vs present), shorter ( $36 \mu \mathrm{m}, c=105, c^{\prime}=$ $0.7 \mathrm{vs} 48 \mu \mathrm{m}, c=81, c^{\prime}=1.0$ ) female tail, and male present (vs absent). In having a comparatively small body size and nearly continuous lip region, $S$. vietnamense sp. nov. is close to $S$. mucrodens and $S$. truxum, from which it differs in its narrower (14-16 vs more than $20 \mu \mathrm{m}$ broad) lip region, shorter stomatal protruding structure (8-9 vs more than $20 \mu \mathrm{m}$ ) located as usual (vs the anterior tip distinctly behind the level of guiding ring), and pars refringens vaginae absent (vs consisting of two small pieces). Sectonema vietnamense sp. nov. is also similar to S. pseudoventrale Heyns, 1965 in having a short odontostyle, but can be distinguished from this by its narrower (14-16 vs 21-23 $\mu \mathrm{m}$ broad) lip region, shorter (209-242 $\mu \mathrm{m}$ or 2.5-2.9 times the corresponding body diameter vs $123 \mu \mathrm{m}$ or 1.3 times the corresponding body diameter) uterus, shorter $\left(36 \mu \mathrm{m}, c=105, c^{\prime}=0.7\right.$ vs $\left.46-63 \mu \mathrm{m}, c=82-130, c^{\prime}=0.8-1.0\right)$ female tail, shorter (5975 vs $90-95 \mu \mathrm{m}$ ) spicules, and fewer (three or four vs six or seven) ventromedian supplements. Finally, the new species also resembles $S$. tropicum sp. nov., but it can be distinguished from this by its narrower (14-16 vs 19-21 $\mu \mathrm{m}$ broad) lip region, shorter (8-9 vs 20-21 $\mu \mathrm{m}$ at its ventral side) odontostyle, longer (occupying 63-67 vs 52-59\% of total neck length) pharyngeal expansion, more posterior vulva ( $V=54$ vs $V=48-52)$, pars refringens vaginae absent (vs present), shorter (59-75 vs 91-97 $\mu \mathrm{m})$ spicules and higher number of ventromedian supplements (three or four vs one).

\section{Remarks}

The two males from Thái Bình are very similar to those of the type population, but some minor morphometric differences have been also noted: somewhat smaller $(2.71,3.02$ vs 3.13-4.25 mm long) and more obese ( $a=33,35$ vs $a=41-49$ ) body. Such differences have been regarded as instraspecific variation as the number of specimens examined is low and the main morphological and morphometric features are coincident.

\section{Acknowledgements}

We would like to thank the directors of Cuc Phuong National Park and Cao Bang Nature Reserve for issuing relevant permits. This research was supported by the project entitled Aporcelaimidae Mundi: Revisión de la familia Aporcelaimidae Heyns, 1965 (Nematoda, Dorylaimida) (ref. CGL201233239; co-financed FEDER), the German Academic Exchange Service (DAAD) (PKZ 91540366), the Zoological Institute (University of Cologne) and IDEAL-WILD (United State). We thank Dr. Tam Vu for providing the specimens from Thai Binh and Idea-Wild (United States of America) for supporting the first author during her master thesis. SEM pictures were obtained with the assistance of technical staff and equipment of "Centro de Instrumentación Científico-Técnica (CICT)", University of Jaén.

\section{References}

Abolafia J. \& Peña-Santiago R. 2005. Nematodes of the order Rhabditida from Andalucía Oriental: Pseudacrobeles elongatus (de Man, 1880) comb. n. Nematology 7 (6): 917-926. http://dx.doi. org/10.1163/156854105776186415

Álvarez-Ortega S., Nguyen T.A.D., Abolafia J., Vu T.T.T. \& Peña-Santiago R. 2015. Three new species of the genus Aporcelaimoides Heyns, 1965 from Vietnam (Nematoda, Dorylaimida, Aporcelaimidae), and an updated taxonomy of the genus. ZooKeys 516: 1-26. http://dx.doi.org/10.3897/zookeys.516.10087 
Álvarez-Ortega S. \& Peña-Santiago R. 2013. Taxonomy of the genus Aporcelaimellus Heyns, 1965 (Nematoda, Dorylaimida, Aporcelaimidae). Zootaxa 3669: 243-260. http://dx.doi.org/10.11646/zootaxa.3669.3.3

Álvarez-Ortega S., Subbotin S.A.\& Peña-Santiago R. 2013a. Morphological and molecularcharacterization of Californian species of the genus Metaporcelaimus Lordello, 1965 (Dorylaimida, Aporcelaimidae), with a new concept of the genus. Nematology 15 (3): 251-278. http://dx.doi.org/10.1163/15685411-00002674

Álvarez-Ortega S., Subbotin S.A. \& Peña-Santiago R. 2013b. Morphological and molecular characterization of Californian species of the genus Aporcelaimellus Heyns, 1965 (Dorylaimida: Aporcelaimidae). Nematology 15 (4): 431-439. http://dx.doi.org/10.1163/15685411-00002691

Baermann G. 1917. Eine einfache Methode zur Auffindung von Ankylostomum (Nematoden) Larven in Erdproben. Geneeskunding Tijdschrift voor Nederlandsch-Indië 57: 131-137.

Coomans A. \& Loof P.A.A. 1986. Observations on the glands of the male reproductive system in dorylaims and its phylogenetic importance. Revue de Nématologie 9 (3): 261-265.

Flegg J.J.M. 1967. Extraction of Xiphinema and Longidorus species from soil by a modification of Cobb's decanting and sieving technique. Annals of Applied Biology 60 (3): 429-437. http://dx.doi. org/10.1111/j.1744-7348.1967.tb04497.x

Holterman M., Rybarczyk K., van den Elsen S., van Megen H., Mooyman P., Peña-Santiago R., Bongers T., Bakker J. \& Helder J. 2008. A ribosomal DNA-based framework for the detection and quantification of stress-sensitive nematode families in terrestrial habitats. Molecular Ecology Resources 8 (1): 23-34. http://dx.doi.org/10.1111/j.1471-8286.2007.01963.x

Huelsenbeck J.P. \& Ronquist F. 2001. MRBAYES: Bayesian inference of phylogenetic trees. Bioinformatics 17 (8): 754-755. http://dx.doi.org/10.1093/bioinformatics/17.8.754

Loof P.A.A. \& Coomans A. 1970. On the development and location of the oesophageal gland nuclei in the Dorylaimina. Proceedings of the I $X^{\text {th }}$ International Nematology Symposium (Warsaw, Poland, 1967): 79-161.

Nicholas K.B., Nicholas Jr H.B. \& Deerfield II D.W. 1997. GeneDoc: analysis and visualization of genetic variation. EMBnet News 4: 1-14.

Nylander J.A.A. 2002. MrModeltest v1.0b. Department of Systematic Zoology, Uppsala University.

Peña-Santiago R., Abolafia J. \& Álvarez-Ortega S. 2014. New proposal for a detailed description of the dorylaim spicule (Nematoda: Dorylaimida). Nematology 16 (9): 1091-1095. http://dx.doi. org/10.1163/15685411-00002834

Peña-Santiago R. \& Álvarez-Ortega S. 2014a. Studies on the genus Sectonema Thorne, 1930 (Dorylaimida: Aporcelaimidae). Re-description of S. ventrale, the type species of the genus. Nematology 16 (9): 1097-1104. http://dx.doi.org/10.1163/15685411-00002837

Peña-Santiago R. \& Álvarez-Ortega S. 2014b. Re-description of three species of the genus Sectonema Thorne, 1930 (Nematoda: Dorylaimida: Aporcelaimidae) originally studied by E. Altherr. Zootaxa 3881: 63-74. http://dx.doi.org/10.11646/zootaxa.3881.1.5

Ronquist F. \& Huelsenbeck J. 2003. MrBayes 3: Bayesian phylogenetic inference under mixed models. Bioinformatics 19 (12): 1572-1574. http://dx.doi.org/10.1093/bioinformatics/btg180

Siddiqi M.R. 1964. Studies on Discolaimus spp. (Nematoda: Dorylaimidae) from India. Zeitschrift für Zoologische Systematik und Evolutionsforschung 2: 174-184. http://dx.doi.org/10.1111/j.1439-0469.1964. tb00720.x 
Subbotin S.A., Sturhan D., Chizhov V.N., Vovlas N. \& Baldwin J.G. 2006. Phylogenetic analysis of Tylenchida Thorne, 1949 as inferred from D2 and D3 expansion fragments of the 28S rRNA gene sequences. Nematology 8 (3): 455-474. http://dx.doi.org/10.1163/156854106778493420

Swofford D.L. 2003. PAUP*: phylogenetic analysis using parsimony (*and other methods). Version 4.0b 10. Sunderland, MA, USA, Sinauer Associates.

Tamura K., Stecher G., Peterson D., Filipski A. \& Kumar S. 2013. MEGA6: Molecular Evolutionary Genetics Analysis version 6.0. Molecular Biology and Evolution 30: 2725-2729. http://dx.doi. org $/ 10.1093 / \mathrm{molbev} / \mathrm{mst} 197$

Thompson J.D., Gibson T.J., Plewniak F., Jeanmougin F. \& Higgins D.G. 1997. The ClustalX windows interface: flexible strategies for multiple sequence alignment aided by quality analysis tools. Nucleic Acids Research 25 (24): 4876-4882. http://dx.doi.org/10.1093/nar/25.24.4876

Manuscript received: 2 September 2015

Manuscript accepted: 22 October 2015

Published on: 15 January 2016

Topic editor: Rudy Jocqué

Desk editor: Charlotte Thionois

Printed versions of all papers are also deposited in the libraries of the institutes that are members of the EJT consortium: Muséum national d'Histoire naturelle, Paris, France; Botanic Garden Meise, Belgium; Royal Museum for Central Africa, Tervuren, Belgium; Natural History Museum, London, United Kingdom; Royal Belgian Institute of Natural Sciences, Brussels, Belgium; Natural History Museum of Denmark, Copenhagen, Denmark. 